\title{
A review of prostate cancer imaging, positron emission tomography, and radiopharmaceutical- based therapy
}

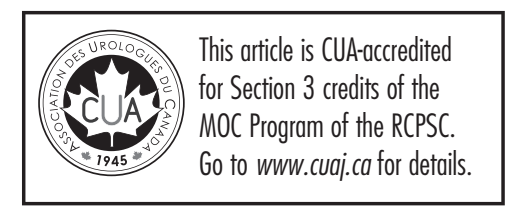

\author{
Amy Pawson ${ }^{*}$; Zonia Ghumman, MD²; Phillip H. Kuo, MD, PhD; Hossein Jadvar, MD, PhD";

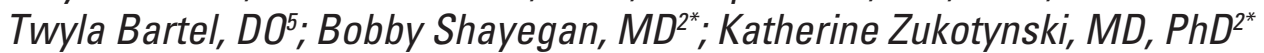

\section{*Equal contributors}

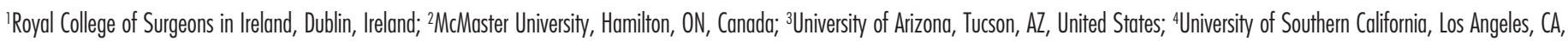
United States; ${ }^{5}$ Global Advanced Imaging, PLLC, Little Rock, AR, United States

Cite as: Can Urol Assoc J 2020;14(4):130-8. http://dx.doi.org/10.5489/cuaj.6506

\section{Introduction}

The prostate gland weighs approximately $20 \mathrm{~g}$ and is situated at the base of the bladder surrounding the prostatic urethra. It can be divided into the peripheral, central, transitional, and peri-urethral zones. ${ }^{1}$ The peripheral zone is the most common site of prostate cancer, and adenocarcinoma accounts for most cases, typically developing from acinar cells in the prostate gland with an associated increase in serum prostatespecific antigen (PSA). Several tumor types, such as neuroendocrine tumors, small-cell carcinoma, and transitional-cell carcinoma, have little effect on PSA. Also, several factors are associated with increased risk of developing prostate cancer, including, among others, age, race, family history, environmental factors, and genetic predisposition.

According to the Canadian Cancer Society, it is estimated that one in nine Canadian men will be diagnosed with prostate cancer during their lifetime, and one in 29 will die from it. ${ }^{2}$ Over the last decade, prostate cancer mortality has been decreasing, possibly due to improved screening and treatment. ${ }^{3}$ Although a topic of debate, screening includes a digital rectal examination (DRE) and PSA level. In 2017, the Canadian Urological Association (CUA) recommended PSA screening be offered to men 50 or over (45 in the case of increased risk) with life expectancy $>10$ years, following a discussion of the potential benefits and harms. ${ }^{4}$ For men electing to have PSA screening, it is recommended that intervals between testing be individualized based on PSA levels. Specifically, if: 1) PSA 1-3 ng/ml, recommend repeat PSA testing every two years; and 2) PSA $\geq 3 \mathrm{ng} / \mathrm{ml}$, consider more frequent PSA testing or adjunctive strategies. The age at which screening is discontinued should be based on PSA level and life expectancy. In men age 60 with PSA $<1$ ng/ ml, consider discontinuing screening, otherwise consider discontinuing screening at age 70 or when life expectancy $<10$ years. The five-year survival is estimated to be approximately $100 \%$ for men with localized disease or regional disease spread, dropping to $30 \%$ in men with distant disease. ${ }^{5}$ Sites of prostate cancer spread include, most commonly, the lymph nodes, bone, liver, and lungs.

\section{A bird's eye view of imaging used in men with prostate cancer}

Several imaging modalities, such as transrectal ultrasound (TRUS) and TRUS-guided prostate gland biopsy, magnetic resonance imaging (MRI), computed tomography $(\mathrm{CT})$, 99mTc-methylene diphosphonate bone scan ( ${ }^{99 m}$ Tc-MDP bone scan), and positron emission tomography (PET), are helpful for prostate cancer staging and management planning. Below, we provide a brief overview of and best practices for prostate cancer imaging and radiopharmaceutical-based therapy (Table 1).

\section{TRUS}

In men clinically suspected to have prostate cancer, following PSA and DRE, TRUS combined with biopsy is the conventional next recommended step. ${ }^{6}$

TRUS is frequently the initial imaging study used to assess the prostate gland in men clinically suspected to have prostate cancer, possibly in part because it does not have ionizing radiation, is relatively inexpensive, and is accessible. It is helpful to estimate gland volume and guide biopsy needle placement. However, prostate cancer may be occult on TRUS, and when present, can be challenging to differentiate from benign proliferative nodules. The sensitivity and specificity of TRUS for the detection of multi- 


\begin{tabular}{|c|c|}
\hline $\begin{array}{l}\text { TRUS and TRUS- } \\
\text { guided prostate gland } \\
\text { biopsy }\end{array}$ & $\begin{array}{l}\text { In men suspected to have prostate } \\
\text { cancer, following PSA testing and DRE } \\
\text { for screening, TRUS combined with } \\
\text { biopsy is typically the next step. }\end{array}$ \\
\hline $\begin{array}{l}\text { MRI and MRI-guided } \\
\text { prostate gland biopsy }\end{array}$ & $\begin{array}{l}\text { MRI with MRI-guided prostate gland } \\
\text { biopsy may be helpful in men with } \\
\text { negative TRUS biopsy and elevated PSA. } \\
\text { MRI can be used to: 1) inform biopsy } \\
\text { decisions and stage men, particularly } \\
\text { those with intermediate to high risk of } \\
\text { extension beyond the capsule; and 2) } \\
\text { re-evaluate men deemed suitable for } \\
\text { active surveillance based on PSA, TRUS, } \\
\text { and biopsy. }\end{array}$ \\
\hline CT and bone scan & $\begin{array}{l}\text { In men at risk of prostate cancer spread, } \\
\text { CT and bone scan are standard of care } \\
\text { for detecting disease in soft tissue } \\
\text { and bone. }\end{array}$ \\
\hline PET & $\begin{array}{l}\text { Several PET radiopharmaceuticals } \\
\text { may be helpful for imaging men with } \\
\text { prostate cancer. Although not standard } \\
\text { of care in Canada, access to PSMA PET } \\
\text { is rising, may show disease with low } \\
\text { PSA }(<0.2 \mathrm{ng} / \mathrm{ml}) \text {, and often results in a } \\
\text { management change compared with } \\
\text { CT and bone scan. }\end{array}$ \\
\hline $\begin{array}{l}{ }^{223} \mathrm{RaCl} 2 \text { (Xofigo; } \\
\text { Bayer Healthcare } \\
\text { Pharmaceuticals) }\end{array}$ & $\begin{array}{l}\text { In men with metastatic CRPC, }{ }^{223} \mathrm{RaCl}_{2} \text { is } \\
\text { recommended for reducing symptomatic } \\
\text { skeletal events and prolonging survival. } \\
\text { The recommended dose for }{ }^{223} \mathrm{RaCl}_{2} \text { is } \\
\text { one IV injection of } 55 \mathrm{kBq} / \mathrm{kg} \text { of body } \\
\text { weight every } 4 \text { weeks for a total of } 6 \\
\text { injections. ANC } \geq 1.5 \times 10^{9}, \mathrm{platelets} \\
\geq 100 \times 10^{9} / \mathrm{L} \text {, hemoglobin } \geq 10 \mathrm{~g} / \mathrm{dL} \text { prior } \\
\text { to the first administration of }{ }^{223} \mathrm{RaCl}_{2} . \\
\text { Subsequently, ANC } \geq 1 \times 10^{9} \text { and platelet } \\
\text { count } \geq 50 \times 10^{9} / \mathrm{L} \text { is adequate. The most } \\
\text { common side effects include anemia, } \\
\text { neutropenia, thrombocytopenia, bone } \\
\text { pain, diarrhea, nausea, vomiting, and } \\
\text { constipation, but they are most often } \\
\text { mild and manageable. }{ }^{223} \mathrm{RaCl}_{2} \text { should } \\
\text { be discontinued if hematological values } \\
\text { do not recover in } 6-8 \text { weeks despite } \\
\text { supportive care. }\end{array}$ \\
\hline $\begin{array}{l}{ }^{177} \text { Lutetium-PSMA } \\
\text { radioligand therapy } \\
\left({ }^{177} \text { Lu-RLT) }\right.\end{array}$ & $\begin{array}{l}\text { There is no recommendation for } \\
{ }^{177} \mathrm{Lu} \text { - RLT yet. }\end{array}$ \\
\hline \multicolumn{2}{|c|}{$\begin{array}{l}\text { ANC: absolute neutrophil count; CT: computed tomography; DRE: digital rectal exam; IV: } \\
\text { intravenous; MRI: magnetic resonance imaging; PET: positron emission tomography; PSA: } \\
\text { prostate-specific antigen; PSMA: prostate-specific membrane antigen; TRUS: transrectal } \\
\text { ultrasound. }\end{array}$} \\
\hline
\end{tabular}

focal disease is estimated to be only $40-50 \%, 7,8$ and the prediction of extracapsular extension has accuracy ranging from $37-83 \%{ }^{9-11}$ Hodge et al suggested that a combination of random systematic and directed biopsies to abnormal areas not included in systematic sampling is the preferred technique. ${ }^{12}$ However, regardless of technique, only a small amount of the gland is sampled during a TRUS biopsy, and the sensitivity and specificity for multi-focal disease is limited. Use of various ultrasound techniques (high-frequency, Power Doppler, color Doppler, three-dimensional Doppler, contrast, and elastography) are being investigated and may improve this.

\section{MRI}

$M R I$ and MRI-guided prostate gland biopsy are helpful in men with negative TRUS biopsy and elevated PSA. ${ }^{13} \mathrm{MRI}$ appears to be helpful to: 1) inform biopsy decisions and stage men with prostate cancer, particularly those men with intermediate to high risk of extension beyond the capsule; and 2) re-evaluate men deemed to be suitable for active surveillance based on PSA, TRUS, and biopsy.

Prostate MRI includes several imaging sequences. While the optimal technique remains to be standardized across institutions, T1- and T2-weighted MR images, dynamic contrast-enhanced (DCE) imaging, and diffusion weighted imaging (DWI) are often included. T1- and T2-weighted MR images are helpful to delineate prostate gland anatomy, localize tumor, and assess extracapsular spread. DCE imaging helps assess disease spread, recurrence, response to antiangiogenic therapy, and provides prognostic information, although false positive results may be seen in the setting of prostatitis. DWI may improve disease detection, although it is limited in the setting of hemorrhage. The apparent diffusion coefficient (ADC), calculated from the DWI, provides prognostic information. MR spectroscopy (MRS) is rarely included but may be helpful. Normal prostate tissue contains low levels of creatine and choline but high levels of citrate, reversed in prostate cancer. MRS showing a ratio of (creatine + choline)/citrate greater than 0.75 in a tissue voxel suggests prostate cancer, and the ratio is thought to correspond with Gleason score. ${ }^{14}$ Although not mandatory, endorectal coils can improve the signal-to-noise ratio (SNR).

A systematic review suggested the sensitivity of MRI for the diagnosis of prostate cancer within the prostate gland was $78 \%$ (95\% confidence interval $[\mathrm{Cl}] 75-81),{ }^{15}$ while a meta-analysis suggested the sensitivity of MRI for the detection of disease spread to lymph nodes was $39 \%(95 \% \mathrm{Cl}$ 22-56). ${ }^{16}$ Several recent clinical trials are of interest. The PROMIS trial ${ }^{17}$ of 576 men with prostate MRI followed by TRUS biopsy and template prostate mapping found MRI had a sensitivity of $93 \%(95 \% \mathrm{Cl} 88-96)$, a specificity of $41 \%$ (95\% Cl 36-46), a positive predictive value (PPV) of 51\% $(95 \% \mathrm{Cl} 46-56)$, and a negative predictive value (NPV) of $89 \%(95 \% \mathrm{Cl} 83-94)$ for detecting cancer in the prostate gland, while TRUS-guided biopsy had a sensitivity of $48 \%$ (95\% Cl 42-55), a specificity of $96 \%$ (95\% Cl 94-98), a PPV of $90 \%(95 \% \mathrm{Cl} 83-94)$, and a NPV of $74 \%(95 \% \mathrm{Cl}$ 69-78). The authors suggested an MRI followed by a TRUS- 
guided biopsy in men with suspected prostate cancer, with re-biopsy if clinically significant prostate cancer was not detected, could be a cost-effective strategy. The PRECISION trial ${ }^{18}$ compared TRUS-guided biopsy to MRI-guided biopsy in 500 men and found more men with prostate cancer were identified using MRI and targeted biopsy than using TRUSguided biopsy alone (38\% vs. $26 \%$ ). The MRI-FIRST trial ${ }^{19}$ of 251 men showed no significant difference in the detection of prostate cancer between systematic and targeted biopsy. While MRI prior to biopsy was found to improve the detection of prostate cancer, it did not obviate the need for a systematic biopsy. ${ }^{19}$

Overall, the literature on prostate MRI is limited by technical variations between studies, including differences in sequences used, magnet strength (1.5 T vs. $3 \mathrm{~T})$, and the method of biopsy. Of note, men with a negative MRI require monitoring, since a negative result does not exclude disease. Currently, MRI is not routine standard of care across Canada for the evaluation of men with suspected disease, largely due to issues of accessibility, cost, time required for the examination, and variable sensitivity and specificity for the detection of disease depending on the technique used.

\section{CT and bone scan}

In men at risk for prostate cancer spread, CT and bone scan are the standard of care imaging studies used for detecting disease in soft tissue and bone. ${ }^{20,21}$

$\mathrm{CT}$ is the workhorse of most radiology practices, with relatively good ability to detect soft tissue and bone disease, although the detection of soft tissue disease is complemented by MRI, and the detection of bone disease is complemented by bone scan. The main limitation of CT is difficulty detecting disease in the absence of anatomi$\mathrm{cal} /$ morphological change. In general, CT is performed in patients with intermediate-/high-risk or suspected disease spread to lymph nodes and/or bone. ${ }^{20,21}$

The radiopharmaceutical (radioactive drug that has met regulatory requirements for administration to patients) used for skeletal scintigraphy (the typical "bone scan") is ${ }^{99 m}$ TcMDP. The radiopharmaceutical is primarily taken up at sites of osteoblastic turnover over a period of approximately 3-4 hours and incorporated into the mineral component of bone. As such, a bone scan does not image bony metastatic disease directly, but rather shows the reaction of the bone to tumor infiltration. Thus, image interpretation can be challenging, since bone repair from traumatic injury may produce a similar appearance to metastatic disease, and the flare phenomenon may show increased uptake. The flare phenomenon on a bone scan within three months of therapy is typically due to a reparative process and characterized by increased lesion intensity or number in the setting of improved PSA. ${ }^{22-25}$ To clarify whether increased lesion intensity or number indicates response to treatment or disease progression, a followup bone scan done after approximately 4-6 months of therapy may be helpful. The bone scan index can be used to quantify total skeletal disease by summing the product of the weight and fractional involvement of 158 bones, where each bone is expressed as a percentage of the skeleton; ${ }^{26}$ however, this is very rarely used in practice. More commonly, a subjective interpretation of disease burden is given. The addition of single photon emission computed tomography (SPECT) to planar imaging may improve contrast and localization. Table 2 summarizes the National Comprehensive Cancer Network (NCCN) guidelines for the use of bone scan, CT, and MRI in men with prostate cancer. ${ }^{21}$

\section{PET for men with prostate cancer}

PET is being increasingly performed in men with prostate cancer to detect sites of disease both at staging and subsequent followup. Today, scanners combine either PET and CT (PET/CT) or PET and MRI (PET/MR) into one hybrid imaging system. Several radiopharmaceuticals can be used with PET (either PET/CT or PET/MRI) scanners, such as ${ }^{18} \mathrm{~F}$-labeled fluorodeoxyglucose $\left({ }^{18} \mathrm{~F}-\mathrm{FDG}\right),{ }^{18} \mathrm{~F}$-labeled sodium fluoride $\left({ }^{18} \mathrm{~F}-\mathrm{NaF}\right),{ }^{11} \mathrm{C}$ - or ${ }^{18} \mathrm{~F}$-labeled choline, ${ }^{11} \mathrm{C}$ - or ${ }^{18} \mathrm{~F}$-labeled acetate, ${ }^{18} \mathrm{~F}$-labeled FACBC $\left({ }^{18} \mathrm{~F}\right.$-fluciclovine), and the prostate-specific membrane antigen (PSMA) family of radiopharmaceuticals. Although the optimal radiopharmaceutical has not yet been defined, a few have been extensively studied and approved for use in other countries (e.g., ${ }^{18} \mathrm{~F}-\mathrm{FDG},{ }^{18} \mathrm{~F}-$ $\mathrm{NaF},{ }^{11} \mathrm{C}$-choline, and ${ }^{18} \mathrm{~F}$-fluciclovine are approved by the U.S. Food and Drug Administration), ${ }^{27}$ in Canada, access to PSMA PET is starting to shape patient management. Best practice is likely to change in the near future regarding the use PET in the diagnostic and treatment approach to men with prostate cancer. In this section, we briefly discuss common PET radiopharmaceuticals that have been assessed in prostate cancer imaging.

\section{${ }^{18}$ F-FDG}

${ }^{18} \mathrm{~F}-\mathrm{FDG}$ is a radiopharmaceutical that is a glucose analogue taken up by cells (both benign and malignant) according to the glycolytic rate (Warburg effect) and as a result of expression of cellular membrane glucose transporters and enhanced hexokinase enzymatic activity in the cell. ${ }^{18} \mathrm{~F}$-FDG PET interpretation is challenging in prostate cancer, as radiopharmaceutical uptake may be limited at sites of disease and in normal and benign tissue. As well, physiological activity related to urinary excretion may be another confounding factor. In a study of 91 men with PSA relapse after prostatectomy, ${ }^{18} \mathrm{~F}-$ FDG PET detected local or systemic disease in only $31 \%$ of patients. ${ }^{28}$ However, the expression of glucose transporter 1 (GLUT1) has been shown to be up-regulated primarily in poorly differentiated, hormone-independent prostate cancer. 


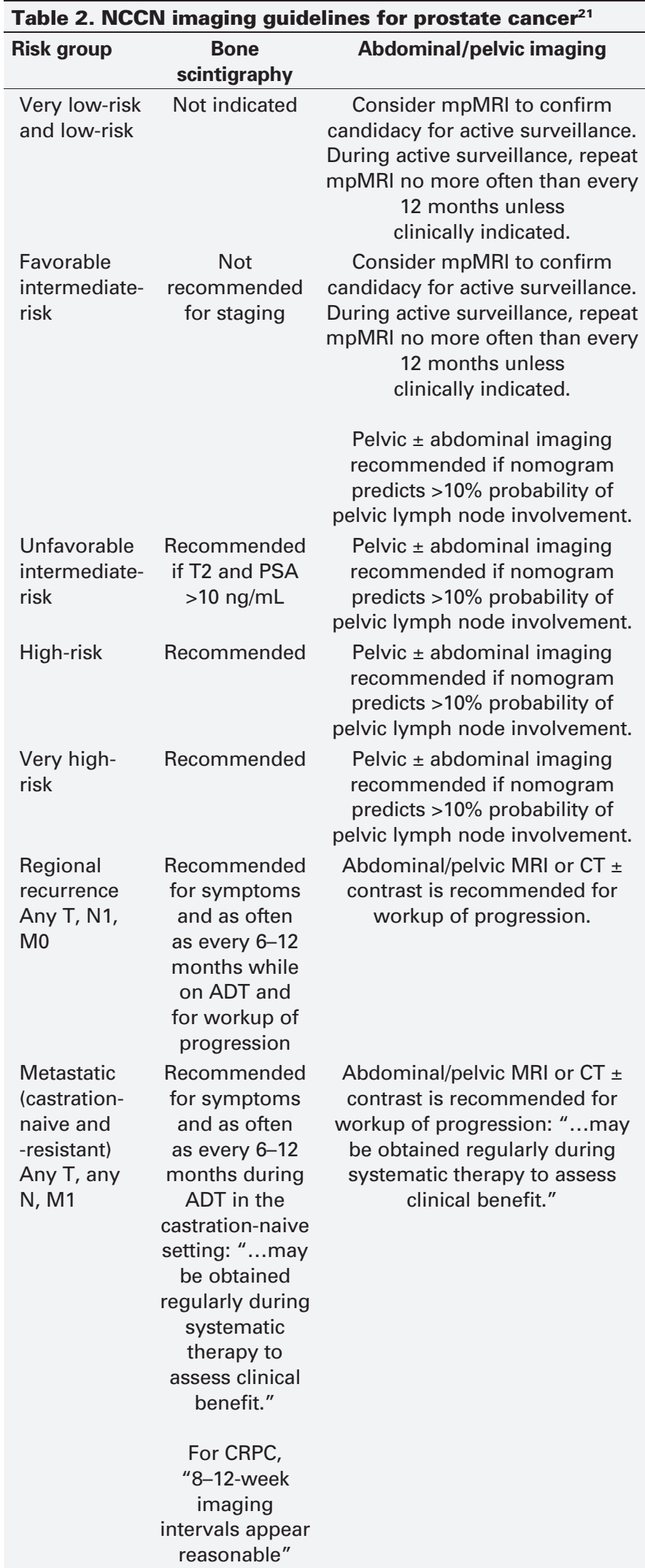

ADT: androgen-deprivation therapy; CRPC: castration-resistant prostate cancer; CT: computed tomography; mpMRI: multiparametric magnetic resonance imaging; NCCN: National Comprehensive Cancer Network.
Thus, ${ }^{18} \mathrm{~F}$-FDG-avid disease suggests higher tumor grade. Generally, it is thought ${ }^{18} \mathrm{~F}$-FDG PET may be particularly helpful in the setting of both castration-sensitive and castrationresistant metastatic disease and in the evaluation of therapy response and prognostication. ${ }^{29-31}$ To date, ${ }^{18} \mathrm{~F}$-FDG PET has played a limited role in staging and followup of men with prostate cancer and is not routinely performed in Canada.

\section{${ }^{18} \mathrm{~F}-\mathrm{NaF}$}

${ }^{18} \mathrm{~F}-\mathrm{NaF}$ is a bone-seeking radiopharmaceutical that is taken up at sites of osteoblastic activity. Similar to ${ }^{99 m}$ Tc-MDP, sites of increased radiopharmaceutical uptake are related primarily to bone turnover and are not specific to metastatic disease. ${ }^{18} \mathrm{~F}-\mathrm{NaF}$ PET has higher sensitivity and specificity for the detection of osseous disease compared with ${ }^{99 \mathrm{~m} T \mathrm{C}-}$ MDP bone scans. For example, Even-Sapir et al reported the sensitivity and specificity of ${ }^{99 \mathrm{~m}} \mathrm{Tc}$-MDP bone scans in men being evaluated for metastases prior to local prostate cancer therapy as $70 \%$ and $57 \%$, respectively, whereas for ${ }^{18} \mathrm{~F}-\mathrm{NaF}$ PET, it was $100 \%$ and $100 \%$, respectively. ${ }^{32}$ Minamimoto et al showed ${ }^{18} \mathrm{~F}-\mathrm{NaF}$ PET had significantly higher sensitivity and accuracy than ${ }^{99 \mathrm{~m} T c-M D P}$ bone scans $(96.2 \%$ vs. $64.6 \%$, $\mathrm{p}<0.001 ; 89.8 \%$ vs. $65.9 \%, \mathrm{p}<0.001$ ) for the detection of skeletal disease. ${ }^{33}{ }^{18} \mathrm{~F}-\mathrm{NaF}$ PET can also be used to provide a semi-quantitative measurement of osteoblastic activity at a site of disease through use of the standardized uptake value (SUV). However, ${ }^{18} \mathrm{~F}-\mathrm{NaF}$ is rarely used in clinical practice today due to issues of accessibility, cost, and reimbursement.

\section{${ }^{11} \mathrm{C}$ - or ${ }^{18} \mathrm{~F}$-labeled choline and ${ }^{11} \mathrm{C}$ - or ${ }^{18} \mathrm{~F}$-labeled acetate}

These are radiopharmaceuticals associated with the production of phospholipids (lipogenesis) in cellular membranes. Increased uptake in prostate cancer cells is thought to be due, at least in part, to the activity of choline kinase (in the case of choline) and fatty acid synthase (in the case of acetate). There is considerable overlap of choline and acetate radiopharmaceutical uptake in prostate cancer cells, benign prostatic hyperplasia, and normal prostate cells, although in general, the radiopharmaceutical uptake is higher at sites of malignant disease. Several studies have suggested mixed results in terms of the sensitivity and specificity of these radiopharmaceuticals for the detection of prostate cancer, with the success for disease detection likely related to PSA level. ${ }^{34,35}$ Specifically, higher PSA level, higher PSA velocity, and shorter PSA doubling time correlate with a higher detection rate of malignancy. For example, the lesion detection by ${ }^{11} \mathrm{C}$-acetate in men with suspected recurrent disease was estimated to be $59 \%$ when the PSA level was greater than $3 \mathrm{ng} / \mathrm{mL}$, dropping to $4 \%$ when the PSA was $\leq 3 \mathrm{ng} / \mathrm{mL} .^{36}$ Krause et al reported ${ }^{11} \mathrm{C}$-choline detection rates of $36 \%$ for PSA less than $1 \mathrm{ng} / \mathrm{mL}, 43 \%$ for PSA $1-2 \mathrm{ng} / \mathrm{mL}, 62 \%$ for PSA $2-3 \mathrm{ng} / \mathrm{mL}$, and $73 \%$ for PSA $>3 \mathrm{ng} / \mathrm{mL} .{ }^{37}$ There does not appear to be a significant difference in detection rate 
between these radiopharmaceuticals and, currently, they are rarely used in clinical practice due to issues of accessibility, cost, and reimbursement. However, recently, the STOMP trial for men with oligometastatic disease recurrence after local treatment with curative intent, diagnosed with either ${ }^{18} \mathrm{~F}$ or ${ }^{11} \mathrm{C}$ choline PET, suggested early treatment of oligometastatic disease may lead to improved therapy-free survival. ${ }^{38}$ This and other clinical trial results suggest use of $\mathrm{PET} / \mathrm{CT}$ in clinical practice for men with prostate cancer will likely increase in future.

\section{${ }^{18} \mathrm{~F}$-labeled FACBC ( ${ }^{18} \mathrm{~F}$-fluciclovine)}

${ }^{18} \mathrm{~F}$-fluciclovine is a radiopharmaceutical that is a synthetic I-leucine amino-acid analogue and has increased uptake at prostate cancer sites. ${ }^{18} \mathrm{~F}$-FACBC has been shown to have limited sensitivity and specificity for primary prostate cancer localization, although the sensitivity is high in clinically suspected recurrent disease. ${ }^{34,35}$ For example, a study of 596 men reported a sensitivity of $88 \%$ and specificity of $33 \%$ for detection of recurrent disease in the prostate bed. ${ }^{39} \mathrm{~A}$ study of 100 men with prostate cancer relapse showed disease detection in $21 \%$ with PSA $<1 \mathrm{ng} / \mathrm{mL}, 29 \%$ with PSA $1-2 \mathrm{ng} / \mathrm{mL}$, $45 \%$ with PSA $2-3 \mathrm{ng} / \mathrm{mL}$, and $59 \%$ with PSA $>3 \mathrm{ng} / \mathrm{mL} .{ }^{40}$ Recently, ${ }^{18} \mathrm{~F}-\mathrm{FACBC}$ PET in men with biochemical recurrence after primary therapy with curative intent and negative or equivocal findings on standard of care imaging was shown to affect management in approximately $60 \%$ of cases. ${ }^{41}$

\section{Cellular proliferation}

There are a few radiopharmaceuticals that target cellular proliferation and that have been used to image men with prostate cancer. For example, ${ }^{18} \mathrm{~F}-3$ '-deoxy-3'-fluorothymidine (FLT) is phosphorylated by thymidine kinase (TK) 1 and is retained in proliferating cells in relation to the thymidine salvage pathway of DNA synthesis. ${ }^{18} \mathrm{~F}-2^{\prime}$-fluoro-5-methyl-Ibeta-D-arabinofuranosyluracil (FMAU) is a thymidine analog that is phosphorylated by TK (preferentially TK2) and incorporated in DNA. The literature on these radiopharmaceuticals is relatively scant and, in general, further evaluation is needed to determine their exact role in the evaluation of men with prostate cancer. ${ }^{42}$

\section{Receptor imaging}

Several radiopharmaceuticals targeting receptors have been used to image men with prostate cancer. $16 \beta-{ }^{18} \mathrm{~F}$-fluoro$5 \alpha$-dihydrotestosterone $\left({ }^{18} \mathrm{~F}-\mathrm{FDHT}\right)$ is a radiopharmaceutical that targets the androgen receptor and has been shown to have a sensitivity of $63 \%$ for the detection of disease in 20 men with metastatic prostate cancer. ${ }^{43} \mathrm{~A}$ study comparing ${ }^{18} \mathrm{~F}-\mathrm{FDHT}$ and ${ }^{18} \mathrm{~F}-\mathrm{FDG}$ suggested there is disease that is androgen receptor-predominant, disease that is glycolysispredominant, and disease that is androgen receptor- and glycolysis-concordant. ${ }^{44}{ }^{68} \mathrm{Ga}$-labeled bombesin is a radio- pharmaceutical that binds to the gastrin-releasing peptide receptor (GRPR), which is overexpressed in prostate cancer. A recent study of 32 men with biochemically recurrent prostate cancer by Minamimoto et al suggested ${ }^{68} \mathrm{Ga}$-bombesin could be helpful in men with non-contributory standardof-care imaging. ${ }^{45}$

\section{The PSMA family of radiopharmaceuticals}

The PSMA family of radiopharmaceuticals includes a spectrum of radiopharmaceuticals that target PSMA, a type II transmembrane glycoprotein expressed on the surface of cells such as the kidney, small intestine, and salivary gland. It is significantly overexpressed in prostate cancer cells (approximately 100-fold). Recent studies have investigated several different radionuclide-labeled small molecule inhibitors of PSMA, primarily using ${ }^{18} \mathrm{~F}$ and ${ }^{68} \mathrm{Ga}$. While the optimal radiopharmaceutical remains to be determined, it has been shown that PSMA PET has higher sensitivity and specificity for the detection of prostate cancer compared with standard-of-care imaging. ${ }^{46,47}$ Further, PSMA PET results in a change in management in a significant number of men. For example, a prospective, single-arm study of 130 men with biochemical failure post-radical prostatectomy or primary radiotherapy with curative intent for localized prostate cancer showed PSMA PET resulted in a change in management in $87 \%$ of men. ${ }^{48} \mathrm{~A}$ systematic review and meta-analysis by Perera et al, published last year and including 37 articles of 4790 men, showed the number of positive scans increased with increasing PSA: $33 \%$ with PSA $<0.2 \mathrm{ng} / \mathrm{ml}, 45 \%$ with PSA $0.2-0.49 \mathrm{ng} / \mathrm{ml}, 59 \%$ with PSA $0.5-0.99 \mathrm{ng} / \mathrm{ml}, 75 \%$ with PSA $1-1.99 \mathrm{ng} / \mathrm{ml}$, and $95 \%$ with PSA $\geq 2 \mathrm{ng} / \mathrm{ml} .{ }^{49}$ Short PSA doubling time is associated with increased scan positivity. It has also been shown there is heterogeneous uptake of radiopharmaceuticals in men with prostate cancer. More specifically, not all sites of prostate cancer are PSMA-avid, and sites of disease may show uptake of other radiopharmaceuticals, such as ${ }^{18} \mathrm{~F}$-FDG and ${ }^{18} \mathrm{~F}$-choline, among others, although the extent of this heterogeneity is as yet unknown. A recent hot topic of investigation is the use of PET (i.e., ${ }^{18} \mathrm{~F}-$ FDG PET and PSMA PET) to stratify men into those who are likely vs. unlikely to respond to specific therapies.

\section{Targeted radionuclide and radioligand therapy for men with prostate cancer}

Targeted radionuclide therapy (TRT) and targeted radioligand therapy (RLT) refer to the use of radiopharmaceuticals for targeted therapy at the cellular or molecular level. One of the benefits of this therapy is the possibility of informing treatment decisions based on a combination of clinical and imaging findings (often including dosimetry) to determine optimal therapy with minimal toxicity. 


\section{${ }^{223} \mathrm{RaCl}_{2}$ (Xofigo; Bayer Healthcare Pharmaceuticals)}

In men with metastatic castration-resistant prostate cancer (CRPC), ${ }^{223} \mathrm{RaCl}_{2}$ is recommended for reducing symptomatic skeletal events and prolonging survival. ${ }^{50,51}$

${ }^{223} \mathrm{RaCl}_{2}$ is an alpha-emitting radiopharmaceutical that acts as a calcium mimetic and is taken up at sites of osteoblastic activity. It has been shown to extend life in men with CRPC. The ALSYMPCA trial included men with symptomatic CRPC, $\geq 2$ bone metastases, and no known visceral disease who were either post-docetaxel or unfit for docetaxel therapy and found that in the 614 men who received ${ }^{223} \mathrm{RaCl}_{2}$ compared with the 307 men who did not, ${ }^{223} \mathrm{RaCl}_{2}$ increased median overall survival (OS) from 11.3 to 14.9 months and time to first skeletal related event from 9.8 to 15.6 months. ${ }^{50}$ The recommended dose for ${ }^{223} \mathrm{RaCl}_{2}$ is one intravenous injection of $55 \mathrm{kBq} / \mathrm{kg}$ of body weight every four weeks for a total of six injections. Further, it is recommended that men have absolute neutrophil count $(\mathrm{ANC}) \geq 1.5 \times 10^{9}$, platelet count $\geq 100 \times 10^{9} / \mathrm{L}$, and hemoglobin $\geq 10 \mathrm{~g} / \mathrm{dL}$ prior to the first administration of ${ }^{223} \mathrm{RaCl}_{2}$. Subsequently, $\mathrm{ANC} \geq 1 \mathrm{x}$ $10^{9}$ and platelet count $\geq 50 \times 10^{9} / \mathrm{L}$ is considered adequate. The most common side effects of therapy include anemia, neutropenia, thrombocytopenia, bone pain, diarrhea, nausea, vomiting, and constipation, but they are most often mild and manageable. ${ }^{223} \mathrm{RaCl}_{2}$ should be discontinued if hematological values do not recover in 6-8 weeks despite supportive care. A systematic review conducted as part of the program in evidence-based care through Cancer Care Ontario currently recommends ${ }^{223} \mathrm{RaCl}_{2}$ for reducing symptomatic skeletal events and prolonging survival in men with symptomatic metastatic CRPC. ${ }^{51}$

\section{${ }^{177}$ Lutetium-PSMA radioligand therapy ( ${ }^{177}$ Lu-RLT)}

\section{There is no recommendation for ${ }^{177} L u-R L T$ yet.}

${ }^{177} \mathrm{Lu}-\mathrm{RLT}$ are beta-emitting radiopharmaceuticals targeted to PSMA for the treatment of men with prostate cancer. Typically, men receiving ${ }^{177}$ Lu-RLT had metastatic CRPC, PSMA expression on PSMA PET, and at least six weeks of myelosuppressive therapy holiday. The optimal ${ }^{177} \mathrm{Lu}-\mathrm{RLT}$ dose is unknown, although Chakraborty et al suggested 7.4 GBq ${ }^{177}$ Lu-PSMA-617 with up to nine cycles of therapy at six-week intervals was effective. ${ }^{52}{ }^{177} \mathrm{Lu}-\mathrm{RLT}$ is excreted by the kidneys, the majority within the first 48 hours, and men should remain under observation 2-4 hours post-injection. Often the amount of radioactivity administered and local regulations dictate if the therapy is given on an outpatient or an inpatient basis. In either case, staff, patients, and family members must be made aware of and follow general radiation safety precautions.

To date, most studies have shown a response to ${ }^{177} \mathrm{Lu}-\mathrm{RLT}$ in men with CRPC (Fig. 1). ${ }^{53-64}$ For example, Ahmadzadehfar

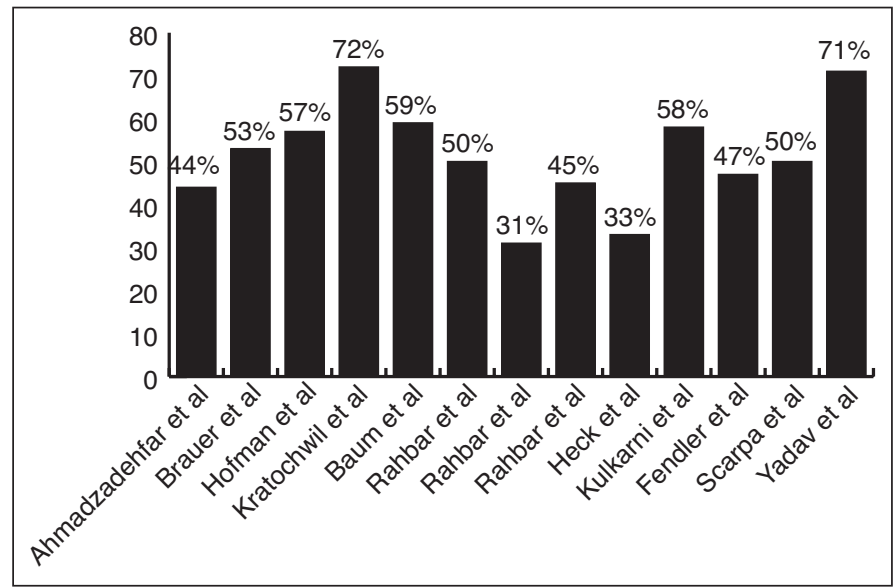

Fig. 1. Percent of patients with a prostate-specific antigen decline of $50 \%$ or more by study.

et al reported $81 \%$ of men had a decline in PSA after one cycle of ${ }^{177}$ Lu-RLT, $44 \%$ with a decrease $\geq 50 \% .{ }^{53}$ Median OS was longer in those men who responded to treatment compared with those who did not (68 weeks vs. 33 weeks). Brauer et al reported similar results with a PSA decline $\geq 50 \%$ in $53 \%$ of men and a decline of any value in $91 \% .{ }^{54}$ Median OS increased in men who responded to one cycle of therapy. In a group of men with PSMA-positive disease and non-FDG-avid disease, Hofman et al reported $57 \%$ had a decline in PSA $\geq 50 \%$, as well as improvement in pain and quality of life. ${ }^{55}$ Despite the apparent success of ${ }^{177}$ Lu-RLT, up to one-third of men may not respond, and identifying those men unlikely to respond remains enigmatic. Also, side effects following therapy have been reported in a minority of men (Table 3). The most common are xerostomia (salivary gland dysfunction), fatigue, nausea, nephrotoxicity, and hematotoxicity. Today, standard treatment for men with CRPC includes a combination of chemotherapy and/ or hormonal agents. A systematic review by Von Eyben et al compared third-line treatment options with ${ }^{177}$ Lu-RLT and concluded ${ }^{177}$ Lu-RLT resulted in a decline in PSA by $>50 \%$ twice as often as chemotherapy and prolonged median OS. ${ }^{65}$ Since myelosuppression limits the amount of radioactivity that can be safely delivered, the ideal time to receive ${ }^{177} \mathrm{Lu}-\mathrm{RLT}$ may be before chemotherapy when higher bone marrow function is present; however, further studies are needed to confirm this. Also, the VISION trial ${ }^{66}$ may provide the needed evidence to support the promise of ${ }^{177} \mathrm{Lu}-\mathrm{RLT}$ in men with metastatic CRPC. More recently, a few studies have focused on the potential utility of RLT labeled with a radionuclide that decays by alpha particle emission (e.g., $\left.{ }^{225} \mathrm{Ac}\right) .{ }^{67,68}$ Again, xerostomia, nephrotoxicity, and hematotoxicity are a concern. Also, with the use of radionuclides, disintegration to daughter particles that may continue to circulate must be taken into consideration as a potential issue that needs to be addressed. 


\begin{tabular}{|c|c|c|c|c|c|c|}
\hline Study & $\begin{array}{l}\text { \# of } \\
\text { men }\end{array}$ & Previous therapy & $\begin{array}{c}\text { RLT/approximate } \\
\text { activity per cycle (GBq) }\end{array}$ & $\begin{array}{l}\text { \# of } \\
\text { cycles }\end{array}$ & $\begin{array}{l}\text { Median overall } \\
\text { survival }\end{array}$ & Side effects \\
\hline $\begin{array}{l}\text { Ahmadzadehfar } \\
\text { et }\left.a\right|^{53}\end{array}$ & 52 & $\begin{array}{l}\text { Hormone therapy, } \\
\text { chemotherapy, } \\
\text { radiation }\end{array}$ & $\begin{array}{c}{ }^{177} \mathrm{Lu}-\mathrm{PSMA}-617 / \\
4-7\end{array}$ & $3-6$ & 60 weeks & NA \\
\hline Brauer et al ${ }^{54}$ & 59 & $\begin{array}{l}\text { Hormone therapy, } \\
\text { chemotherapy, } \\
\text { radiation }\end{array}$ & ${ }^{177}$ Lu-PSMA-617/6 & 3 & 32 weeks & $\begin{array}{l}\text { - } 3 \% \text { grade } 3 \text { thrombocytopenia and } \\
\text { leucopenia } \\
-\quad 19 \% \text { grade } 3 \text { anemia } \\
-\quad 25 \% \text { xerostomia } \\
-\quad 2 \% \text { dry eyes } \\
-\quad 20 \% \text { fatigue }\end{array}$ \\
\hline Hofman et al ${ }^{55}$ & 30 & $\begin{array}{l}\text { Hormone therapy, } \\
\text { chemotherapy, } \\
\text { radiatione }\end{array}$ & ${ }^{177 L u-P S M A-617 / 7.5 ~}$ & 2 & NA & $\begin{array}{l}\text { - } \quad 87 \% \text { grade } 1 \text { xerostomia } \\
\text { - } 50 \% \text { grade } 1-2 \text { nausea } \\
\text { - } 50 \% \text { grade } 1-2 \text { fatigue } \\
\text { - } \quad 13 \% \text { grade } 3-4 \text { thrombocytopenia }\end{array}$ \\
\hline $\begin{array}{l}\text { Kratochwil et } \\
\text { al }^{56}\end{array}$ & 30 & $\begin{array}{l}\text { Hormone therapy, } \\
\text { chemotherapy, } \\
\text { radiation }\end{array}$ & ${ }^{177} \mathrm{Lu}-\mathrm{PSMA}-617 / 4-6$ & $1-3$ & NA & $\begin{array}{l}\text { - } 33 \% \text { anemia (worsening by one } \\
\text { grade compared to baseline) } \\
\text { - } 20 \% \text { grade } 1 \text { leucopenia } \\
-\quad 7 \% \text { grade } 2 \text { leucopenia } \\
-\quad 13 \% \text { grade } 1 \text { thrombocytopenia } \\
-\quad 3 \% \text { grade } 2-3 \text { thrombocytopenia } \\
-\quad 7 \% \text { xerostomia }\end{array}$ \\
\hline Baum et al ${ }^{57}$ & 56 & $\begin{array}{l}\text { Hormone therapy, } \\
\text { chemotherapy, } \\
\text { radiation }\end{array}$ & $\begin{array}{c}{ }^{177} \text { Lu-PSMA- I\&T/ } \\
\text { 3.6-8.7 }\end{array}$ & NA & NA & $\begin{array}{l}-4 \% \text { xerostomia } \\
-\quad 16 \% \text { grade } 1-2 \text { leucopenia }\end{array}$ \\
\hline Rahbar et al ${ }^{58}$ & 28 & NA & ${ }^{177}$ Lu-PSMA-617/NA & 2 & 29 weeks & $\begin{array}{l}-14 \% \text { nausea } \\
-\quad 14 \% \text { xerostomia }\end{array}$ \\
\hline Rahbar et al ${ }^{59}$ & 74 & $\begin{array}{l}\text { Hormone therapy, } \\
\text { chemotherapy, } \\
\text { radiation }\end{array}$ & ${ }^{177}$ Lu-PSMA-617/5.9 & 1 & NA & $\begin{array}{l}-3 \% \text { anemia } \\
-\quad 9 \% \text { xerostomia } \\
-\quad 1 \% \text { nausea }\end{array}$ \\
\hline Rahbar et al ${ }^{60}$ & 145 & NA & ${ }^{177}$ Lu-PSMA-617/2-8 & $1-4$ & NA & $\begin{array}{l}\text { - } 3 \% \text { grade } 3-4 \text { leucopenia } \\
-\quad 10 \% \text { grade } 3-4 \text { anemia } \\
-\quad 4 \% \text { grade } 3-4 \text { thrombocytopenia } \\
-\quad 6 \% \text { nausea } \\
-\quad 8 \% \text { xerostomia }\end{array}$ \\
\hline Kulkarni et al ${ }^{61}$ & 119 & $\begin{array}{l}\text { Hormone therapy, } \\
\text { chemotherapy, } \\
\text { radiation }\end{array}$ & $\begin{array}{l}{ }^{177} \text { Lu-PSMA- I\&T and } \\
{ }^{177} \text { Lu-PSMA-617/ } \\
2-9.7\end{array}$ & $1-7$ & Not yet known & $\begin{array}{l}\text { - } \quad 4 \% \text { xerostomia } \\
-\quad 3 \% \text { grade } 3-4 \text { hemotoxicity }\end{array}$ \\
\hline Fendler et $\mathrm{al}^{62}$ & 15 & $\begin{array}{l}\text { Hormone therapy, } \\
\text { chemotherapy, } \\
\text { radiation }\end{array}$ & $\begin{array}{l}{ }^{177} \text { Lu-PSMA- } 617 / \\
3.7 \text { or } 6\end{array}$ & $1-2$ & NA & - $\quad 7 \%$ grade 3 anemia \\
\hline Scarpa et al ${ }^{63}$ & 10 & $\begin{array}{l}\text { Hormone therapy, } \\
\text { chemotherapy, } \\
\text { radiation }\end{array}$ & $\begin{array}{c}{ }^{177} \text { Lu-PSMA-617/ } \\
5.4-6.5\end{array}$ & $2-3$ & NA & $\begin{array}{l}\text { - } 30 \% \text { xerostomia } \\
\text { - } 20 \% \text { fatigue } \\
\text { - } 10 \% \text { nausea } \\
\text { - } 10 \% \text { constipation }\end{array}$ \\
\hline Yadav et al ${ }^{64}$ & 31 & $\begin{array}{l}\text { Hormone therapy, } \\
\text { chemotherapy, } \\
\text { radiation }\end{array}$ & ${ }^{177}$ Lu-PSMA-617/5 & $1-4$ & NA & $\begin{array}{l}\text { - } \quad 26 \% \text { grade } 1 \text { anemia } \\
-\quad 6 \% \text { had grade } 2-3 \text { anemia } \\
-\quad 3 \% \text { grade } 2 \text { thrombocytopenia }\end{array}$ \\
\hline
\end{tabular}

GBq: gigabecquerel; I\&T: imaging \& therapy; NA: not available.

\section{Summary}

Imaging is essential in the detection, diagnosis, staging, and monitoring of men with prostate cancer. Over the past decade, technical advancements have led to improved sensitivity, specificity, and accuracy of disease detection. Further advances in the availability and use of radiopharmaceuticals for imaging and therapy in men with pros- tate cancer are starting to make their way into clinical practice. Today, in Canada, TRUS-guided biopsy of the prostate gland is still the standard of care for diagnosis, while CT and bone scan remain the standard of care to evaluate distant disease. MRI and MRI-guided biopsy is recommended in men with negative TRUS-guided biopsy and may be helpful to re-evaluate men deemed suitable 
for active surveillance based on PSA, TRUS, and biopsy. ${ }^{223} \mathrm{RaCl}_{2}$ is recommended for reducing symptomatic skeletal events and prolonging survival in men with castrationresistant disease. Although it is likely that PET and RLT will become part of the imaging and therapy armamentarium for men with prostate cancer in the near future, the most effective algorithm is still evolving.

Competing interests: Dr. Kuo has been a member of advisory boards for Bayer (prostate cancer) and Eisai (Alzheimer's); a speaker for Eisai and General Electric Healthcare; a consultant and reader for clinical trials for General Electric Healthcare, Konica Minolta, and Novartis; and participated in clinical trials supported by Blue Earth Diagnostics (Axumin for bone metastases in prostate cancer) and Novartis (VISION Phase 3 trial for prostate cancer theranostics). Dr. Jadvar is a co-investigator with the safety and efficacy assessment of a CD8 PET tracer for use in cancer immunotherapy supported by ImaginAb, and a principle investigator for assessing a deep machine learning algorithm for PET supported by Subtle Med. Dr. Shayegan has been an advisory board member for Astellas, Bayer, and Janssen; and has received a research grant from Janssen. The remaining authors report no competing personal or financial interests related to this work.

This paper has been peer-reviewed

\section{References}

1. The male genital tract, pp. 1025-1034 in Cotran R, Kumar V and Collins T, Robbins Pathologic Basis of Disease 4th Edition.

2. Canadian Cancer Society. Available at: https://www.cancer.ca/en/cancer-information/cancer-type/ prostate/statistics/?region=on. Accessed Jan. 4, 2020.

3. Prostate Cancer Canada, Statistics. Available at: httrp://prostatecancer.ca/Prostate-Cancer/About-ProstateCancer/Statistics. Accessed June 12, 2019.

4. Rendon R, Mason R, Marzouk K, et al. Canadian Urological Association recommendations on prostate cancer screening and early diagnosis. Can Urol Assoc J 2017; 11:298-309. https://doi.org/10.5489/ cuaj.4888

5. American Cancer Society, Survival Rates for Prostate Cancer. Available at: https://www.cancer.org/ cancer/prostate-cancer/detection-diagnosis-staging/survival-rates.html. Accessed Jan. 4, 2020.

6. Izawa Jl, Klotz L, Siemens DR, et al. Prostate cancer screening: Canadian guidelines 2011. Can Urol Assoc J 2011;5:235-40. https://doi.org/10.5489/cuaj.11134

7. Rafkin MD, Zerhouni EA, Gatsonis $C A$, et al. Comparison of magnetic resonance imaging and ultrasonography in staging early prostate cancer. Results of a multi-institutional cooperative trial. N Engl J Med 1990;323:621-6. https://doi.org/10.1056/NEJM199009063231001

8. Beerlage HP, Aarnink RG, Ruijter ET, et al. Correlation of transrectal ultrasound, computer analysis of transrectal ultrasound and histopathology of radical prostatectomy specimen. Prostate Cancer Prostatic Dis 2001;4:56-62. https://doi.org/10.1038/si.pcan.4500495

9. Hamper UM, Sheth S, Walsh PC, et al. Carcinoma of the prostate: Value of transrectal sonography in detecting extension into the neurovascular bundle. AJR Am J Roentgenol 1990;155:1015-9. hitps://doi.org/10.2214/air.155.5.2120928

10. Hamper UM, Sheth S, Walsh PC, et al. Capsular transgression of prostatic carcinoma: Evaluation with transrectal US with pathologic correlation. Radiology 1991;178:791-5. https://doi.org/10.1148/ radiology. 178.3.1994420

11. MCSherry SA, Levy F, Schiebler ML, et al. Preoperative prediction of pathological tumor volume and stage in clinically localized prostate cancer: Comparison of digital rectal examination, transrectal ultrasonography, and magnetic resonance imaging. J Urol 1991;146:85-9. https://doi.org/10.1016/ S0022-5347(17)37720-0

12. Hodge KK, MCNeal JE, Terris MK, et al. Random systematic vs. directed ultrasound guided transrectal core biopsies of the prostate. J Urol 1989;142:71-4. https://doi.org/10.1016/50022-5347(17)38664-0

13. Mason BR, Eastham JA, David BJ, et al. Current status of MRI and PET in the NCCN guidelines for prostate cancer. J Natl Compr Canc Netw 2019;17:506-13. https://doi.org/10.6004/inccn.2019.7306

14. Zukotynski K, Haider M. Imaging in prostate cancer. Hematol Oncol Clin of North Am 2013;27:1163-87. https://doi.org/10.1016/i.hoc.2013.08.003
15. Sathianathen NJ, Butaney $M$, Bongiorno $C$, et al. Accuracy of the magnetic resonance imaging pathway in the detection of prostate cancer: A systematic review and meta-analysis. Prostate Cancer Prostatic Dis 2019;22:39-48. https://doi.org/10.1038/s41391-018-0075-4

16. Hovels AM, Heesakkers RA, Adang EM, et al. The diagnostic accuracy of CT and MRI in the staging of pelvic lymph nodes in patients with prostate cancer: A meta-analysis. Clin Radiol 2008;63:387-95. https://doi.org/10.1016/i.crad.2007.05.022

17. Brown LC, Ahmed HU, Faria R, et al. Multiparametric MRI to improve detection of prostate cancer compared with transrectal ultrasound-guided prostate biopsy alone: The PROMIS study. Health Technol Assess 2018;22:1-176. https://doi.org/10.3310/hta22390

18. Kasivisvanathan V, Rannikko AS, Borghi M, et al. MRl-targeted or standard biopsy for prostate cancer diagnosis. N Engl J Med 2018;378:1767-77. https://doi.org/10.1056/NEJMoal801993

19. Rouviere 0 , Puech $P$, Renard-Penna $R$, et al. Use of prostate systematic and targeted biopsy on the basis of multiparametric MRl in biopsy-naive patients (MRI-FIRST): A prospective, multicenter, paired diagnostic study. Lancet Oncol 2019;20:100-9. https://doi.org/10.1016/S1470-2045(18)30569-2

20. Eberhardt SC, Carter $S$, Casalino DD, et al. ACR appropriateness criteria prostate cancer-pretreatment detection, staging, and surveillance. J Am Coll Radiol 2013;10:83-92. https://doi.org/10.1016/i. jacr.2012.10.021

21. Mohler JL, Lee RJ, Antonarakis ES, et al. NCCN clinical practice guidelines in oncology: Prostate cancer. Version 4.2018.

22. Coleman RE, Mashiter $\mathrm{G}$, Whitaker $\mathrm{KB}$, et al. Bone scan flare predicts successful systemic therapy for bone metastases. J Nucl Med 1988;29:1354-9.

23. Cook GJK, Venkitaraman R, Sohaib AS, et al. The diagnostic utility of the flare phenomenon on bone scintigraphy in staging prostate cancer. Eur J Nucl Med Mol Imaging 2011;38:7-13. https://doi.org/10.1007/s00259-010-1576-0

24. Pollen JJ, Witztum KF, Ashburn WL. The flare phenomenon on radionuclide bone scan in metastatic prostate cancer. AJR Am J Roentgenol 1984;142:773-6. https://doi.org/10.2214/aj.142.4.773

25. Messiou C, Cook G, Reid AHM. The CT flare response of metastatic bone disease in prostate cancer. Acta Radiologica 2011;52:557-61. https://doi.org/10.1258/ar.2011.100342

26. Dennis ER, Jia X, Mezheritskiy IS, et al. Bone scan index: A quantitative treatment response biomarker for castration-resistant metastatic prostate cancer. J Clin Oncol 2012;30:519-24. https://doi.org/10.1200/ JC0.2011.36.5791

27. Jadvar H. Positron emission tomography in imaging evaluation of staging, restaging, treatment response, and prognosis in prostate cancer. Abdom Radiol (NY) 2016;41:889-98. https://doi.org/10.1007/ s00261-015-0563-0

28. Schoder H, Hermann K, Gnen M, et al. ${ }^{2.18}$-ffluorodeoxyglucose positron emission tomography for detection of disease in patients with prostate-specific antigen relapse after radical prostatectomy. Clin Cancer Res 2005;11:4761-9. https://doi.org/10.1158/1078-0432.CCR-05-0249

29. Morris MJ, Akhurst T, Larson SM, et al. Fluorodeoxyglucose positron emission tomography as an outcome measure for castrate metastatic prostate cancer treated with anti-microtubule chemotherapy. Clin Cancer Res 2005; 11:3210-6. hittps://doi.org/10.1158/1078-0432.CCR-04-2034

30. Jadvar H, Desai B, Ji L, et al. Baseline 18F-FDG PET/CT parameters as imaging biomarkers of overall survival in castrate-resistant metastatic prostate cancer. J Nucl Med 2013;54:1195-1201. htrps://doi. org/10.2967/jnumed.112.114116

31. Jadvar $\mathrm{H}$, Velez EM, Desai $\mathrm{B}$, et al. Prediction of time to hormonal treatment failure in metastatic castration-sensitive prostate cancer with 18F-FDG PET/CT. J Nucl Med 2019;60:1524-30. https://doi.org/10.2967/inumed.118.223263

32. Even-Sapir E, Metser U, Mishani E, et al. The detection of bone metastases in patients with high-risk prostate cancer: 99mTc-MDP planar bone scintigraphy, single-, and multifield-of-view SPECT, ${ }^{18 F-f l u o r i d e}$ PET, and ${ }^{18 F-f l u o r i d e ~ P E T / C T . ~ J ~ N u c l ~ M e d ~ 2006 ; 47: 287-97 . ~}$

33. Minamimoto R, Loening A, Jamali M, et al. Prospective comparison of 99mTc-MDP scintigraphy, combined ${ }^{18}$ F-NaF and ${ }^{18 F-F D G ~ P E T / C T}$, and whole-body MRl in patients with breast and prostate cancer. J Nucl Med 2015;56:1862-8. https://doi.org/10.2967/inumed.115.162610

34. Jadvar H. Molecular imaging of prostate cancer: PET radiotracers. AIR Am J Roentgenol 2012;199:278-91. https://doi.org/10.2214/AJR.12.8816

35. $Y_{U} \mathrm{CY}$, Desai $B$, Ji L, et al. Comparative performance of PET tracers in biochemical recurrence of prostate cancer: A critical analysis of literature. Am J Nucl Med Mol Imaging 2014;4:580-601.

36. Oyama N, Miller TR, Dehdashti F, et al. " "C-acetate PET imaging of prostate cancer: Detection of recurrent disease at PSA relapse. J Nucl Med 2003;44:549-55.

37. Krause BJ, Souvatzpglou $M$, Tuncel $M$, et al. The detection rate of $[(11) C]$ choline-PET/CT depends on the serum PSA value in patients with biochemical recurrence of prostate cancer. Eur J Nucl Med Mol Imaging 2008;35:18-23. https://doi.org/10.1007/s00259-007-0581-4

38. Ost P, Reynders D, Decaestecker $K$, et al. Surveillance or metastasis-directed therapy for oligometastatic prostate cancer recurrence: A prospective, randomized, multicenter, phase 2 trial. J Clin Oncol 2018;36:446-53. https://doi.org/10.1200/JC0.2017.75.4853 
39. Bach-Gansmo T, Nanni C, Nieh PT, et al. Multisite experience of the safety, detection rate, and diagnostic performance of fluciclovine (18F) positron emission tomography/computerized tomography imaging in the staging of biochemically recurrent prostate cancer. J Urol 2017;197:676-83. https://doi.org/10.1016/i. juro.2016.09.117

40. Nanni C, Zanoni L, Pultrone C, et al. ${ }^{18}$ F-FACBC (antil-amino-3-18Ffluorocyclobutane-l carboxylic acid) vs. "C-choline PET/CT in prostate cancer relapse: Results of a prospective trial. Eur J Nucl Med Mol Imaging 2016;43:1601-10. https://doi.org/10.1007/s00259-016-3329-1

41. Andriole GL, Kostakoglu L, Chau A, et al. The impact of positron emission tomography with ${ }^{18}$-flucyclovine on the treatment of biochemical recurrence of prostate cancer: Results from the LOCATE trial. J Urol 2019;201:322-31. https://doi.org/10.1016/i.juro.2018.08.050

42. Jadvar $\mathrm{H}$. Imaging cellular proliferation in prostate cancer with positron emission tomography. Asia Ocean J Nucl Med Biol 2015;3:72-6.

43. Dehdashti F, Picus J, Michalski J, et al. Positron tomographic assessment of androgen receptors in prostatic carcinoma. Eur J Nucl Med Mol Imaging 2005;32:344-50. https://doi.org/10.1007/s00259-005 1764-5

44. Fox J, Blanc E, Schoder $\mathrm{H}$, et al. Diversity of biology in castrate resistant prostate cancer. J Nucl Med 2009:50:523.

45. Minamimoto R, Sonni I, Hancock S, et al. Prospective evaluation of ${ }^{68}$ Ga-RM2 PET/MR in patients with biochemical recurrence of prostate cancer and negative findings on conventional imaging. J Nucl Med 2018:59:803-8. https://doi.org/10.2967/inumed.117.197624

46. Fendler WP, Calais J, Eiber M, et al. Assessment of ${ }^{68} \mathrm{Ga}$-PSMA- 11 PET accuracy in localizing recurrent prostate cancer: A prospective, single-arm clinical trial. JAMA Oncol 2019;5:856-63. hitps://doi. org/10.1001/jamaoncol.2019.0096

47. Calais J, Ceci F, Eiber M, et al. ${ }^{18}$ F-fluciclovine PET-CT and ${ }^{68}$ Ga-PSMA-11 PET-CT in patients with early biochemical recurrence after prostatectomy: A prospective, single-center, single-arm, comparative imaging trial. Lancet Oncol 2019;20:1286-94. https://doi.org/10.1016/S1470-2045(19)30415-2

48. Rousseau E, Wilson D, Lacroix-Poisson F, et al. A prospective study on ${ }^{18 F-D C F P y L ~ P S M A ~ P E T / C T ~ i m a g i n g ~}$ in biochemical recurrence of prostate cancer. J Nucl Med 2019;60:1587-93. https://doi.org/10.2967/ jnumed.119.226381

49. Perera $M$, Papa N, Roberts $M$, et al. Gallium-68 prostate-specific membrane antigen positron emission tomography in advanced prostate cancer-updated diagnostic utility, sensitivity, specificity, and distribution of prostate-specific membrane antigen-avid lesions: A systematic review and meta-analysis. Eur Urol 2019; [Epub ahead of print]. https://doi.org/10.1016/i.eururo.2019.01.049

50. Parker C, Nilsson S, Heinrich D, et al. Alpha emitter radium-223 and survival in metastatic prostate cancer. N Engl J Med 2013;369:213-23. https://doi.org/10.1056/NEJMoal213755

51. Alibhai SMH, Zukotynski K, Walker-Dilks C, et al. Bone health and bone-targeted therapies for prostate cancer: A program in evidence-based care - Cancer Care Ontario clinical practice guideline. Clin Oncol 2017;29:348-55. https://doi.org/10.1016/i.clon.2017.01.007

52. Chakraborty $S$, Chakravarty R, Shetty $P$, et al. Prospects of medium specific activity (177) Lu in targeted therapy of prostate cancer using (177) Lu-labeled PSMA inhibitor. J Labelled Comp Radiopharm 2016:59:364-71. https://doi.org/10.1002/ikr.3414

53. Ahmadzadehfar $\mathrm{H}$, Wegen $\mathrm{S}$, Yordanova $\mathrm{A}$, et al. Overall survival and response pattern of castrationresistant metastatic prostate cancer to multiple cycles of radioligand therapy using [(177)Lu] Lu-PSMA-617. Eur J Nucl Med Mol Imaging 2017;44:1448-54. https://doi.org/10.1007/s00259-017-3716-2

54. Braver A, Grubert LS, Roll W, et al. ${ }^{177}$ Lu-PSMA-617 radioligand therapy and outcome in patients with metastasized castration-resistant prostate cancer. Eur J Nucl Med Mol Imaging 2017;44:1663-70. https://doi.org/10.1007/s00259-017-3751-z

55. Hofman MS, Violet J, Hicks RJ, et al. ${ }^{177}$ LU-PSMA-617 radionuclide treatment in patients with metastatic castration-resistant prostate cancer (LuPSMA trial): A single-center, single-arm, phase 2 study. Lancet Oncol 2018;19:825-33. https://doi.org/10.1016/S1470-2045(18)30198-0
56. Kratochwil C, Giesel FL, Stefanova M, et al. PSMA-targeted radionuclide therapy of metastatic castration-resistant prostate cancer with ${ }^{177}$ Lu-labeled PSMA-617. J Nucl Med 2016;57:1170-6. https://doi.org/10.2967/inumed.115.171397

57. Baum RP, Kulkarni HR, Schuchardt C, et al. ${ }^{177}$ Lu-labeled prostate-specific membrane antigen radioligand therapy of metastatic castration-resistant prostate cancer: Safety and efficacy. J Nucl Med 2016;57:100614. https://doi.org/10.2967/jnumed.115.168443

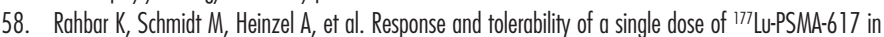
patients with metastatic castration-resistant prostate cancer: A multicenter, retrospective analysis. J Nucl Med 2016:57:1334-8. https://doi.org/10.2967/inumed.116.173757

59. Rahbar K, Bode A, Weckesser M, et al. Radioligand therapy with ${ }^{177}$ Lu-PSMA-617 as a novel therapeutic option in patients with metastatic castration-resistant prostate cancer. Clin Nucl Med 2016;41:522-8. https://doi.org/10.1097/RLU.0000000000001240

60. Rahbar K, Ahmadzadehfar $\mathrm{H}$, Kratochwil C, et al. German multicenter study tnvestigating ${ }^{177}$ Lu-PSMA-617 radioligand therapy in advanced prostate cancer patients. J Nucl Med 2017;58:85-90. https://doi.org/10.2967/inumed.116.183194

61. Kulkarni HR, Singh A, Schuchardt C, et al. PSMA-based radioligand therapy for metastatic castrationresistant prostate cancer: The sad Berka experience since 2013. J Nucl Med 2016;57:97s-104s. https://doi.org/10.2967/inumed.115.170167

62. Fendler WP, Reinhardt $\mathrm{S}$, Ihan $\mathrm{H}$, et al. Preliminary experience with dosimetry, response, and patientreported outcome after ${ }^{177}$ Lu-PSMA-617 therapy for metastatic castration-resistant prostate cancer. Oncotarget 2017;8:3581-90. https://doi.org/10.18632/oncotarget.12240

63. Scarpa L, Buxbaum S, Kendler D, et al. The ${ }^{68} \mathrm{Ga} /{ }^{177} \mathrm{Lu}$ theragnostic concept in PSMA targeting of castrationresistant prostate cancer: Correlation of SUVmax values and absorbed dose estimates. Eur J Nucl Med Mol Imaging 2017;44:788-800. https://doi.org/10.1007/s00259-016-3609-9

64. Yadav MP, Ballal S, Tripathi M, et al. ${ }^{177 L u-D K F Z-P S M A-617}$ therapy in metastatic castration-resistant prostate cancer: Safety, efficacy, and quality of life assessment. Eur J Nucl Med Mol Imaging 2017;44:8191. https://doi.org/10.1007/s00259-016-3481-7

65. von Eyben FE, Roviello G, Kiliunen T, et al. Third-line treatment and ${ }^{177}$ Lu-PSMA radioligand therapy of metastatic castration-resistant prostate cancer: A systematic review. Eur I Nucl Med Mol Imaging 2018;45:496-508. https://doi.org/10.1007/s00259-017-3895-x

66. Study of ${ }^{177}$ Lu-PSMA-617 in metastatic castrate-resistant prostate cancer (VISION). Available at: https://clinicaltrials.gov/c+2/show/NCT03511664. Accessed Dec. 8, 2019.

67. Kratochwil C, Bruchertseifer $\mathrm{F}$, Rathke $\mathrm{H}$, et al. Targeted -therapy of metastatic castration-resistant prostate cancer with 225AC-PSMA-617: Swimmer-plot analysis suggests efficacy regarding duration of tumor control. J Nucl Med 2018;59:795-802. https://doi.org/10.2967/inumed.117.203539

68. Stahekge $M$, Bruchertseifer $F$, Vorster $M$, et al. Predictors of overall and disease-free survival in metastatic castration-resistant prostate cancer patients receiving 225Ac-PSMA-617 radioligand therapy. J Nucl Med 2020;61:62-9. https://doi.org/10.2967/inumed.119.229229

Correspondence: Dr. Katherine Zukotynski, McMaster University, Hamilton, ON, Canada; katherine.zukotynski@utoronto.ca

To answer the multiple-choice questions associated with this article, go to: www.cuasection3credits.org/cuajapril2020. This program is an Accredited Self-Assessment Program (Section 3) as defined by the Maintenance of Certification Program of The Royal College of Physicians \& Surgeons of Canada, and approved by the Canadian Urological Association. Remember to visit MAINPORT (www.mainport.org/mainport/) to record your learning and outcomes. You may claim a maximum of 1 hour of credit. 